\title{
COLUMN
}

\section{(Herstel)recht en excuses: een precaire relatie}

\author{
Vincent Geeraets
}

Excuses vormen een hot topic. ${ }^{1}$ Onder wetenschappers dringt steeds meer het besef door dat slachtoffers niet alleen behoefte hebben aan compensatie, maar dat er ook emotionele noden zijn. Het ontvangen van een verontschuldiging is in dat kader belangrijk. Maar leent het recht zich er wel voor om excuses te faciliteren of te stimuleren? En hoe zit het in dat verband met het herstelrecht? Geeft herstelbemiddeling een vruchtbare voedingsbodem voor het maken van excuses? Ik heb daar de nodige twijfel bij. Het ondersteunen van excuses is vergelijkbaar met het streven naar geluk. Al te directe pogingen in die richting corrumperen: de excuses zijn niet waarachtig en het geluk wordt niet gevonden.

Gijs Van Dijck doet een voorstel ter ondersteuning van het maken van excuses. ${ }^{2}$ In zijn optiek zou een slachtoffer in een civiel geding niet alleen een vergoeding moeten kunnen vragen voor de geleden schade, maar zou hij ook de mogelijkheid moeten hebben om excuses te vorderen. Als de rechter een dergelijke vordering proportioneel acht, zou hij de vordering moeten toekennen. Daarbij is het denkbaar dat de rechter een sanctie verbindt aan het niet nakomen van deze verplichting. Ik vind dit een spannend, maar ook problematisch voorstel. Het hoofdprobleem is niet eens zozeer dat het maken van opgelegde excuses waarschijnlijk niet heel oprecht zal zijn, maar meer nog dat de tegenpartij vernederd lijkt te worden. Hij raakt de controle kwijt over zijn eigen stem en wordt geïnfantiliseerd. Als een ouder of een onderwijzer aan een minderjarig kind te verstaan geeft dat hij 'sorry' moet gaan zeggen tegen een klasgenoot, dan kan dat vanuit pedagogisch oogpunt wellicht heel verantwoord zijn. Maar kun je zoiets ook vergen van een volwassene?

Iemand die zich ook hard maakt voor het faciliteren van excuses is Arno Akkermans. ${ }^{3}$ Hij geeft aan dat het voor patiënten heel belangrijk is om excuses te krijgen als er medische fouten zijn gemaakt. In de praktijk blijkt echter dat artsen ervoor terugschrikken om zich expliciet te verontschuldigen, omdat dit gevolgen kan hebben voor de aansprakelijkheid van de zorgverlener. Dat leidt ertoe dat patiënten niet, of pas heel laat, een spijtbetuiging ontvangen, hetgeen niet bevorderlijk is voor hun emotionele herstel. Akkermans pleit daarom voor het loskop-

1 Zo ook op een recente en interessante expertmeeting 'Victims within Criminal Trials' aan de VU, georganiseerd door Iris Becx, Gabriele Chlevickaite, Nieke Elbers en Barbora Hola. Zie ook Tijdschrift voor herstelrecht, 2018, 18(1).

2 Gijs van Dijck (2017) The Ordered Apology. Oxford Journal of Legal Studies, 37(3), 562-87. Zie ook V. Geeraets \& W. Veraart (2017) Over verplichte excuses en spreekrecht. Netherlands Journal of Legal Philosophy, 46(2), 137-159.

3 Zie bijvoorbeeld een co-publicatie met J. Legemaate \& R.D. Vriele (2015) Openheid over medische fouten: waar staan we?. Nederlands Tijdschrift voor Geneeskunde, 159. 
pelen van excuses en juridische aansprakelijkheid. Dit lijkt een sympathiek idee, maar er zijn ook bezwaren. Is het niet gratuit - zeker bij ernstige gevolgen - om excuses te maken als je je tegelijkertijd hebt afgeschermd voor eventuele juridische consequenties en dus juist niet bereid bent om verantwoordelijkheid te nemen voor de consequenties van je handelen? Als kenmerk van excuses wordt vaak aangenomen dat de persoon die excuses maakt de controle uit handen geeft. Het is aan de andere partij om aan te geven wat een eventuele vervolgstap zou kunnen zijn, bijvoorbeeld welke vorm van reparatie of compensatie hij of zij wenselijk acht. Het idee van Akkermans is echter juist om de controle over de consequenties van de te maken excuses zo veel mogelijk te behouden. Dat roept de vraag op of het idee van loskoppeling niet vooral is ingegeven door de wens om de patiënt te pacificeren met behulp van een panacee.

De voorgaande voorbeelden dragen een privaatrechtelijke signatuur, maar excuses vormen ook een belangrijk onderwerp binnen het strafrecht. Een vraag waar rechtsgeleerden al langer mee worstelen, is in hoeverre het aanbieden van excuses invloed mag hebben op de op te leggen straf. Ook hier dreigt een gevaar van corrumpering. Als door het aanbieden van een verontschuldiging een lagere straf kan worden bewerkstelligd, dan zal een verdachte met acteertalenten daar allicht handig gebruik van maken. Toch zijn excuses op een indirecte manier wel degelijk van belang voor de strafmaat, omdat het bijdraagt aan het beeld dat de rechter zich zal moeten vormen over de proceshouding van de verdachte. Het lijkt mij voor de hand liggend dat een dader die uitleg geeft hoe hij tot zijn daad gekomen is en daar excuses voor aanbiedt, minder straf zou moeten krijgen dan bijvoorbeeld een dader die aangeeft de verwerpelijkheid van zijn gedraging niet te willen respecteren en daarmee laat blijken het zo weer te doen. In dat laatste geval valt te bepleiten dat de rechter de maximale straf oplegt.

Het voorgaande laat zien dat er redenen kunnen zijn waarom het recht het maken van excuses in beperkte mate faciliteert. Bij uitstek is het recht geschikt om financiële zorgen van gedupeerden te verlichten, maar het leent zich er maar matig voor om aan emotionele noden tegemoet te komen. Het recht kan wel de portemonnee van de tegenpartij/dader raken, maar niet zijn schuldbewustzijn of compassie afdwingen zonder zijn innerlijk, in meer of mindere mate, te manipuleren of te corrumperen.

Herstelbemiddeling is op het eerste gezicht een stuk beter geëquipeerd om het maken van excuses te ondersteunen. Het gaat hier om een - in vergelijking met het strafrecht - informele ontmoeting waarbij slachtoffer en dader zich kunnen uiten op een manier die henzelf goeddunkt. Zij blijven - om de beroemde woorden van Nils Christie te gebruiken - eigenaar van het conflict. Toch is er ook hier reden voor zorg. De dader heeft weliswaar zelf gekozen om deel te nemen aan de bemiddeling, maar hij weet dat aan niet-deelnemen (strafrechtelijke) gevolgen zijn verbonden. Voor een dader-met-acteertalent zou het daarom aantrekkelijk kunnen zijn om een toneelstuk op te voeren. Daarnaast - en dit wordt ook steeds 
meer erkend binnen herstelrechtelijke literatuur ${ }^{4}$ - werkt de herstelbemiddeling met een script: eerst moet worden verteld wat er is gebeurd, daarna dient de dader verantwoordelijkheid te nemen voor wat hij heeft gedaan en ten slotte dienen afspraken te worden gemaakt over compensatie. De vrijheid binnen herstelbemiddeling is daarmee toch vrij beperkt en dat betekent dat ook hier een gevaar dreigt van een de facto afgedwongen compassie.

Het is voor veel slachtoffers van groot belang om excuses te krijgen, zeker als zij op een kwalijke manier zijn gedupeerd. Toch denk ik dat het voor wetenschappers belangrijk is om uit te blijven leggen dat het maken van excuses een persoonlijke kwestie is - een gewetensbeslissing - waar noch het recht noch de herstelbemiddeling helemaal vat op kan of zou moeten krijgen.

4 Zie bijvoorbeeld B. van Stokkom (2018) Jonge daders: worstelen met sorry-zeggen. Tijdschrift voor Herstelrecht, 18(1). Zie ook mijn V. Geeraerts (2014) Herstelrechtelijke ficties. Rechtsgeleerd Magazijn Themis, 175(2), 72-79. 